\title{
Chapter 15 \\ Multifunctional Urban Landscapes: The Potential Role of Urban Agriculture as an Element of Sustainable Land Management
}

\section{Kathrin Specht, Julian Schimichowski, and Runrid Fox-Kämper}

\begin{abstract}
Urban agriculture (UA) has long been the subject of civic and scientific debate, since it provides cities with a diverse range of functions and services. UA is thought to have a positive effect on sustainable urban development in environmental, economic and social areas. Although most of the effects attributed to UA are positive, there are also critical aspects and concerns. For example, doubts have been raised about the quality of the products grown, considering the prevalence of air pollution and contaminated soils; and there are doubts about the contribution that urban agriculture makes to feeding urban populations, owing to the small quantities produced. Moreover, there are conflicts surrounding land use, especially in big cities; and in some cases, agricultural activities are undertaken in the city without the necessary building approvals. The concept of co-production and sharing as a (business) model is increasingly being applied with reference to urban gardens. This is particularly the case with volunteer-led community gardens, which are tremendously open to gardening enthusiasts and are renowned for the sharing of resources and space. Rather than seeking to make a profit, many of these initiatives operate under the principles of a non-profit or sharing economy. This chapter explores how UA can contribute to sustainable land management and co-production. To this end, background information is given on the (re-)emerging phenomenon of urban food production and on what motivates those involved to implement collaborative practices. The functions and services provided by UA as an element of sustainable land management are then explored using the three pillars of sustainability.
\end{abstract}

\footnotetext{
K. Specht $(\bowtie) \cdot$ R. Fox-Kämper

Research Institute for Regional and Urban Development (ILS), Brüderweg 22-24, 44135

Dortmund, Germany

e-mail: kathrin.specht@ils-forschung.de

R. Fox-Kämper

e-mail: runrid.fox-kaemper@ils-forschung.de

J. Schimichowski

Master Graduate Spatial Planning - Technische Universität Dortmund, August-Schmidt-Straße 1, 44227 Dortmund, Germany

e-mail: jschimichowski@gmail.com
} 
Keywords Alternative Food Networks (AFN) $\cdot$ Co-Production $\cdot$ Sustainability • Consumer-producer relationships $\cdot$ Urban gardening

\subsection{Background on Urban Agriculture}

There has been an enormous increase in UA activities throughout the world in the recent past, as evidenced by the growing interest in allotment gardening and urban gardening (BMUB 2015). And yet the production of food in the city is not a new phenomenon - it has been common practice ever since cities evolved. According to Colding and Barthel (2013), the emergence of UA is closely linked to crisis-prone developments in the city. The term "crisis" refers primarily to times of economic upheaval, although it can also be extended to social transformations (Fox-Kämper 2016). Thus allotments emerged around the mid-nineteenth century in response to the poor housing and supply conditions experienced by the urban population of European cities that swelled as a result of industrialisation, whereas the growing popularity of community gardens since the mid-1970s is partly a response to the growing polarisation, fragmentation and segregation of the urban population (CalvetMir et al. 2016). In view of globalised food markets, the development of current types of urban agriculture also reflects an increasing desire for traceability and knowledge about the origin of food and the interplay involved in its production.

Especially in view of shrinking cities and regions - for example owing to postreunification phenomena in Germany or structural change - people are currently in search of approaches that can bring about stabilisation and improvement. New ideas and approaches are needed to embrace today's urban reality, which is marked by the coexistence of shrinking and growing regions. The concept of "Continuous Productive Urban Landscapes" (CPUL), proposed by architects and urban designers Katrin Bohn and André Viljoen, seeks to integrate agriculture into urban planning, and to make it an essential element of sustainable infrastructure (Schulz et al. 2013; Viljoen et al. 2005). This example illustrates today's continued relevance of UA for urban planning. In contrast to the past, however, UA is only rarely pursued to enable the urban population to become self-sufficient (Schulz et al. 2013). As indicated above, UA was popular whenever populations suffered deprivation and hardship. It is therefore all the more surprising that UA has become such a widespread phenomenon in prosperous cities in developed countries of the Global North, resulting in the evolvement of a "new urban agriculture" (Karge 2015). Appel et al. (2011) identify the emerging green movement in the 1970s and the effects of the Chernobyl disaster in the mid-1980s as starting points for the renaissance of UA (Appel et al. 2011). This was a time when alternative lifestyles and economic systems were being debated and put to the test, particularly in Germany, because the Western economic model had led to mistrust and uncertainty among the population, owing to an increase in fragility. In the light of concerns about the finite nature of fossil resources, growing numbers of people asked themselves how they, as individuals, could lead more sustainable lives (Lohrberg 2011). Growing food can therefore be regarded as an alternative to 
globalised food markets and a consumerist lifestyle. Then there are social motivations - many urban gardens are tended communally, and serve as places of integration and openness towards the urban environment (Lohrberg 2011).

Internationally, "urban agriculture" is considered to be an umbrella term for all types of food production in the city. Whereas central importance was attached to food production in early definitions of the term (UNDP 1996), more recent definitions recognise the diversity of the different types of UA, which provide the city with other services apart from food:

Urban agriculture spans all actors, communities, activities, places and economies that focus on biological production in a spatial context, which - according to local standards - is categorized as 'urban'. Urban agriculture takes place in intra- and periurban areas [...] urban agriculture is structurally embedded in the urban fabric; it is integrated into the social and cultural life, the economics, and the metabolism of the city. (Vejre et al. 2016, 21).

The following table lists examples of different types of UA. Their boundaries are blurred or may overlap in some cases, and are not always clear-cut (Table 15.1).

\subsection{Motivations for UA: New Consumer-Producer Relationships and Co-production}

The notion of sharing as a (business) principle is increasingly applied with reference to urban gardens. This is particularly the case with volunteer-led community gardens, which are characterised by tremendous openness towards gardening enthusiasts and by the sharing of resources and space (Zoll et al. 2018; Opitz et al. 2017). Rather than seeking to make a profit, many of these initiatives operate under the principles of a non-profit or sharing economy (Piorr et al. 2018; De Cunto et al. 2017). The principle of sharing is evident in collaboration among the volunteers and in the sharing of resources (land, money, labour and means of production) as well as crops and knowledge.

Figure 15.1 shows the focus of different types of UA. While some types of UA (such as home gardens) are merely practised in a private setting, with no engagement involved, other types of UA are largely shaped by elements of collaboration and co-production. For example, interaction between members is a key element of community gardens, which are geared towards social networking, whereas interaction between producers and consumers is the core of the business model when it comes to community-supported agriculture, for instance.

The main reason for the particular relevance of collaboration and co-production in UA is that the marketing of food produced in UA differs considerably from that in commercial agriculture. Food grown in urban settings is usually marketed locally, i.e. it is consumed in the city where it was grown. Whereas the food produced by established large farms is usually traded on the world market, UA is characterised by direct marketing (RUAF Foundation). While urban gardens tend to be small-scale 
Table 15.1 Different types of urban agriculture, and their main characteristics

\begin{tabular}{|c|c|}
\hline Type of urban agriculture & Main characteristics \\
\hline Home gardens & $\begin{array}{l}\text { - Affiliated with individual households } \\
\text { - Not institutionally embedded }\end{array}$ \\
\hline $\begin{array}{l}\text { Allotments (also referred } \\
\text { to as family gardens) }\end{array}$ & $\begin{array}{l}\text { - Plots for individual use, e.g. for the non-commercial } \\
\text { production of food, usually in specific complexes } \\
\text { - Institutionally embedded in acts and planning law }\end{array}$ \\
\hline Self-harvest gardens & $\begin{array}{l}\text { - Plots that have been pre-tilled by farmers, and are } \\
\text { individually tended by urban residents who grow their } \\
\text { own vegetables } \\
\text { - Leases, usually for a season }\end{array}$ \\
\hline Community gardens & $\begin{array}{l}\text { - Volunteer-led gardens for communal use } \\
\text { - Often as interim use concepts on brownfield or infill sites; } \\
\text { no institutional backing }\end{array}$ \\
\hline Intercultural gardens & $\begin{array}{l}\text { - A special type of community garden with the aim of } \\
\text { fostering integration }\end{array}$ \\
\hline Therapeutic gardens & $\begin{array}{l}\text { - Often affiliated with psychotherapy institutions } \\
\text { - Doing gardening and experiencing the garden may have a } \\
\text { healing effect on patients }\end{array}$ \\
\hline School gardens & $\begin{array}{l}\text { - Usually affiliated to schools } \\
\text { - The aim is to teach children about how to grow, process } \\
\text { and prepare food, and about the environment }\end{array}$ \\
\hline Social farming & $\begin{array}{l}\text { - Managed farms operated by institutions responsible for } \\
\text { social welfare establishments } \\
\text { - By handling farmed animals or plants, individuals are } \\
\text { given the opportunity to relax and perform work-related } \\
\text { activities }\end{array}$ \\
\hline School farms & $\begin{array}{l}\text { - Further development of the traditional use of farms } \\
\text { - The aim is to provide children with an educational and } \\
\text { recreational facility in a near-natural environment }\end{array}$ \\
\hline Community-supported agriculture & $\begin{array}{l}\text { - A community of producers and consumers comprising } \\
\text { farms and private households } \\
\text { - Seasonal contractual relationship between producers and } \\
\text { consumers }\end{array}$ \\
\hline Local direct marketing & $\begin{array}{l}\text { - Direct marketing of agricultural products - generally in } \\
\text { farm shops }\end{array}$ \\
\hline
\end{tabular}

projects that may meet a few households' demand for food, market oriented urban agriculture can also be practised on large-scale farms (Opitz et al. 2016).

In the process, UA does not only produce material goods. On the urban periphery in particular, farms have adopted strategies to adapt their range of services, which are usually aimed at local or regional markets. The strategies for UA mentioned by Piorr et al. (2018) include specialisation, differentiation and diversification. Specialisation in a few specific products enables production costs to be cut and the functional proximity to urban areas to be exploited. In this way, for example, highly perishable products that are only feasible for short transport distances can be marketed with a 


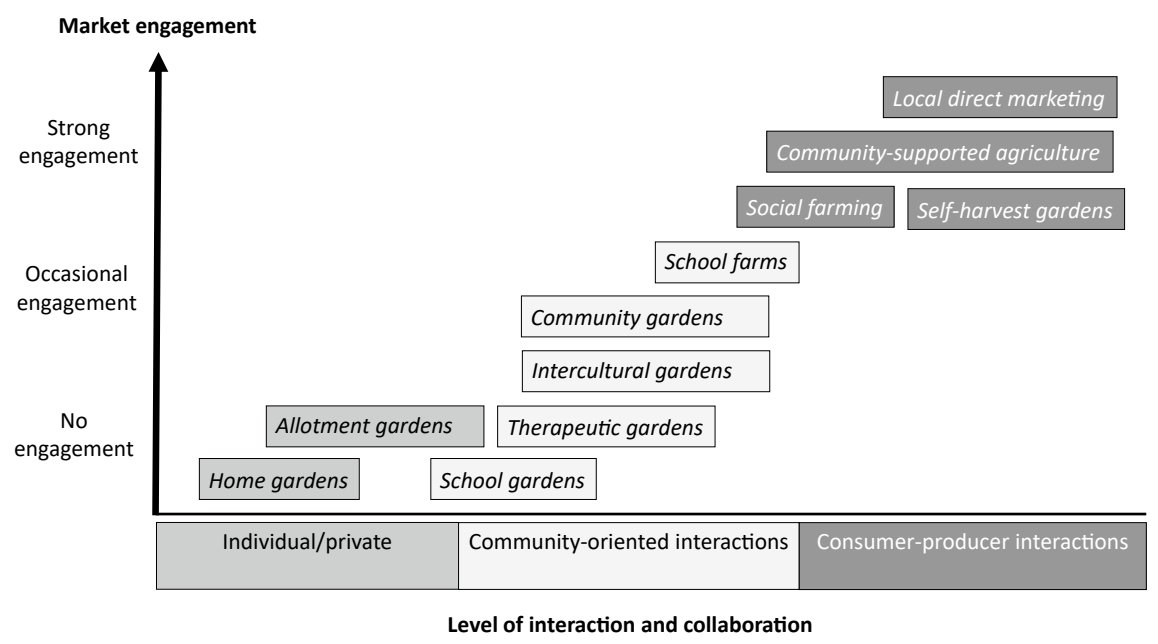

Fig. 15.1 Collaboration and level of market engagement in different types of UA (source: authors)

competitive advantage over rural agriculture. Differentiation can involve growing old varieties or especially high-quality products, for instance. Diversification enables UA projects to expand their portfolio by offering services such as horse management or educational activities in addition to food (Piorr et al. 2018; van der Schans et al. 2016). All operational strategies place emphasis on strong regional networking structures.

In the historical context, UA was mostly linked to the motivation of subsistence. The primary actors in UA today have different reasons for growing food in an urban setting. The three typical types of motivation named by Berges et al. (2014) are (1) an emphasis on subsistence, (2) a socio-cultural emphasis and (3) an emphasis on commerce (Berges et al. 2014). Those who place an emphasis on subsistence pursue the goal of producing their own food by their own efforts, along with the added monetary, health and recreational benefits. This also ties in with the motivation to supply oneself with fresh produce, and to create and pass on knowledge about food production (van der Jagt et al. 2017). Environmental considerations are another important reason for getting involved in agricultural activity, enabling possibilities for more sustainable urban food production to be tested in cities that are apparently becoming increasingly disconnected from nature (van der Jagt et al. 2017; Smit et al. 2001; Vejre et al. 2016). The key objectives of activities with a socio-cultural emphasis are community-building, cultural exchange, education and social inclusion (Berges et al. 2014, 12). Such activities are often politically motivated. An anti-capitalist stance and a rejection of the globalised food system are reflected in some UA initiatives (McClintock and Simpson 2017). Other UA activities seek to appropriate urban space, and to demand the "right to the city" (Horst et al. 2017, 283; Thibert 2012; Holm 2011; Purcell and Tyman 2015). The main objective behind the commercial emphasis is to generate income and profit, create jobs, and develop new markets. 
With reference to UA, Appel et al.(2011) mention, in particular, the possibility to create a new type of open space "that may be the starting point for collective grassroots processes, practised autonomy and networking, and that may play an important role in promoting (local) politics" (Appel et al. 2011, 152, translated by authors). This enables UA stakeholders to actively shape a part of the city, based on their own ideas (Appel et al. 2011).

Those engaged in UA can broadly be classified into two groups. The first group comprises people who carry out farming as their usual main occupation, whether parttime or full-time. They may have deliberately chosen the proximity to an urban area, or may have experienced urban growth encroach on their farm over time. The second group comprises individuals who practise UA as a hobby in their spare time (Vejre et al. 2016). These two UA subgroups differ. Above all, urban gardens are usually tended as a hobby, whereas urban agriculture tends to be practised by professional actors.

\subsection{Functions and Services Provided by UA Concerning Sustainable Land Management}

The functions and services of UA mentioned in the scientific debate are extremely varied. As a multifunctional service, UA has, in principle, the potential to have a positive impact on social, ecological and economic concerns in cities (Schulz et al. 2013). Based on Pearson et al. (2010), the services are presented below using the three pillars of sustainability. Where possible, reference is made to sustainable land management.

\subsubsection{Social Functions and Services}

Various studies have documented that UA may contribute to strengthening the social capital of the city (Santo et al. 2016). In particular, the notion of multifunctionality of the city should be stressed in this respect. There are social demands, for example, with regard to additional services provided in the areas of leisure, recreation and education. Being green spaces in a city, urban gardens may make an important contribution to the city landscape and to increasing the quality of life in urban spaces.

This is achieved by creating new networks between actors from different social backgrounds and milieus, which is particularly the case with community gardens. In this context, services conducive to the integration of disadvantaged social groups are attributed to UA projects (Santo et al. 2016; RUAF Foundation). These social services are also achieved by creating new places of interaction and encounter, which, particularly in neighbourhoods with a lack of green space, improve residential quality and may result in a higher level of identification with the neighbourhood (Appel et al. 
2011). Added value is generated by creating leisure activities to enhance physical and mental health, promoting general health and well-being (RUAF Foundation, Piorr et al. 2018). As an element of sustainable land management, therefore, urban gardens make an important contribution to neighbourhood development. The result is a "new sense of community, prospects for shaping one's own life; and gardening encourages participants to become more deeply engaged in the neighbourhood" (BBSR 2015, 5; translated by authors). UA also makes a contribution to practical environmental education by enabling individuals to experience first-hand how food is produced (Gahm 2017; Appel et al. 2011). In that regard, UA induces a change in consumer behaviour, one that is more sustainable, because it enables passive consumers to become co-producers of food (Santo et al. 2016).

\subsubsection{Ecological Functions and Services}

UA increases the heterogeneity of urban land uses, contributing to the urban ecosystem (Sanyé-Mengual et al. 2018; Artmann and Sartison 2018). The additional vegetation grown increases biodiversity in urban spaces. In addition, inner-city urban gardens may help to balance the temperature and reduce heat islands (Santo et al. 2016). The fresh air produced also helps improve air quality (BMUB 2015). Moreover, UA generates new infiltration areas. After all, sealed brownfield sites are often converted into land for UA, which has a positive impact on the groundwater and on flood protection (Santo et al. 2016; Piorr et al. 2018). UA may also help to reduce waste by recycling organic waste and waste water as part of the urban material cycle or urban metabolism (Roggema 2016; de Zeeuw 2011). In general, the ecological functions described may make cities more resilient to climate change and, at the same time, contribute to mitigate climate change (Piorr et al. 2018; Santo et al. 2016). This is also achieved because local food production reduces transport distances - referred to as food miles - as well as the energy consumption involved, e.g. for cooling food, reducing the overall level of pollutant emissions (Piorr et al. 2018; Pearson et al. 2010).

\subsubsection{Economic Functions and Services}

First of all, UA performs economic services with respect to urban farmers and gardeners because food is grown, easing the financial burden on households. Farmers and gardeners either sell produce to this end, or consume it themselves (RUAF Foundation). However, the emphasis on subsistence is less important in post-industrial nations of the Global North. In these countries, economic advantages can be generated instead by developing business strategies tailored specifically to the framework conditions of urban spaces (Piorr et al. 2018). As such, UA may generate jobs and create employment opportunities in the local value chains (Santo et al. 2016). Furthermore, 
the concept of "social entrepreneurship" is common in UA, and alternative economic models that focus on greater cooperation between consumers and producers often come to fruition. UA therefore promotes a diversified urban economy and added value by way of urban production (Brandt et al. 2018; Pearson et al. 2010). This also helps cities to become more resilient in terms of food supply and food security (BMUB 2015). As with other green infrastructure, UA may help to upgrade urban neighbourhoods, stemming a decline in value of urban infrastructure and real estate (Voicu and Been 2008), particularly in regions affected by shrinkage. Municipalities also benefit from UA, such as when green spaces are tended communally by garden initiatives, reducing the financial burden on cities (Rosol 2006; Stierand 2012).

\subsubsection{Limitations}

Aside from these positive attributions, there are also voices in the academic debate that challenge the functions and services provided by UA, or at least limit them. For example, it is said that, although locally initiated urban gardens improve neighbourhoods, they may ultimately encourage gentrification processes and damage the neighbourhood's social fabric (Cohen and Reynolds 2014; Specht et al. 2017; Horst et al. 2017). There is also criticism that the oft-touted tremendous openness may not signify openness for everyone. After all, the use of former public open spaces for urban gardens excludes non-gardeners from using these spaces, raising doubts about whether they are indeed of interest to the general public (Sondermann 2014). With reference to the integrating effect of UA, mostly associated with intercultural gardens, it is noted that colonial ways of thinking are re-inscribed in that the better-off bring good food to disadvantaged social groups (McClintock et al. 2016).

Another key limiting factor that must be mentioned is the availability of land, which is a necessary condition for any kind of UA. Undeveloped areas are highly sought after, particularly in growing cities with a high influx of newcomers, resulting in strong competition for land use and high land prices. In this context, inner-city urban gardens particularly compete with investors usually keen to implement real estate projects, e.g. for residential purposes (Schmidt 2016; Berges et al. 2014; BMUB 2015). Since urban gardens are mostly projects that are initiated and run by residents, they are financially inferior to commercial real estate development and usually unable to compete successfully for urban open spaces (Berges et al. 2014). As a result, land reserves are increasingly being covered with buildings, and urban greenery and urban gardens are in conflict with other uses (BMUB 2015). This situation is exacerbated by the principle of "inner development before outer development" defined in the many national building codes - e.g for Germany in the Federal Building Code (BauGB) (Siedentop 2010; Koch 2017). The aim of this requirement is to reduce land consumption, which leads to the re-densification of central areas and fewer building land designations as urban expansion. Concerning the availability of land for urban gardens, this means that more infill sites are developed, more brownfields are covered with buildings, and more land is recycled, putting even greater 
pressure on urban open spaces (Schmidt 2016; BMUB 2015; Siedentop 2010). The bigger the city and the greater influx it experiences, the more this situation is exacerbated. This is especially true for cities that experience a high influx of newcomers and are particularly appealing to young people (Simons and Weiden 2016). Growth dynamics, and therefore the pressure on open spaces, are particularly high in such cities. Then again, limiting settlement development on the outskirts of the city leads to the securing of land for UA initiatives located in those areas, because it reduces the excess planning of agricultural land on the outskirts. UA is thus largely influenced by the availability of land (Berges et al. 2014).

The situation is opposite in shrinking cities, where there is ample land for UA (Dams 2012). In this respect, for example, the structural availability of brownfield sites in former industrial regions may potentially promote UA, whereas cities in prosperous metropolitan regions exhibit higher land prices and commercialisation pressures, making it more difficult for UA initiatives to develop and persist. Although this finding primarily relates to urban gardens located in urban areas, it can also be applied to peri-urban areas. UA in peri-urban areas runs the risk of farmland being converted into building land. After all from the urban planner's perspective, periurban agricultural areas were long regarded as land reserves for urban development concepts and planning processes (LWK NRW 2012).

The quality of land and its suitability for growing food is also of crucial importance. The availability of other resources such as water, organic waste and soil are the determining factors in this case. Then it could be the case, especially with innercity areas, that soil has been contaminated by previous industrial use, for example, preventing food production or necessitating complex soil remediation measures (Specht and Siebert 2017; Howe et al. 2005).

There are also doubts concerning the independent economic viability of UA projects because they are often a recreational activity and therefore do not have to be economically sustainable (Schulz et al. 2013). The economic capacity of UA and its actual contribution to the food system are also cast into doubt. Compared to conventional farming, the contribution of UA to providing food for the urban population is considered minimal (McEldowney 2017).

In spite of the limitations described, it has been shown that UA may potentially be beneficial to a variety of broader development goals such as sustainability, quality of life, food justice and urban resilience (Horst et al. 2017).

\subsection{Conclusion}

Urban agriculture (UA) has long been the subject of civic and scientific debate. In connection with sustainable land management, UA is especially considered in the context of urban development with the simultaneity of suburbanisation and reurbanisation processes (Schulz et al. 2013; Piorr et al. 2018). The functions and services of UA are manifold. UA has a positive impact on sustainable urban development, e.g. by reducing food miles; economic benefits are created by increasing regional added 
value; social benefits are gained by way of integration and community-building; health effects are produced due to exercise, nutrition and recreation; and environmental advantages are achieved by improving the urban climate (Berges et al. 2014; BMUB 2015). These are just a few of the positive impacts of UA discussed in the scientific literature. The above-mentioned benefits do not apply in equal measure to all types of UA. Moreover, the actors involved differ, as do the motivations for undertaking UA activities, ranging from subsistence and socio-cultural motivations to commercial intentions (Berges et al. 2014). Although most of the effects attributed to UA are positive, there are also critical aspects and concerns. For example, doubts have been raised about the quality of the products grown, considering the prevalence of air pollution and contaminated soils; and there are doubts about the contribution that urban agriculture makes to feeding urban populations, owing to the small quantities produced. Moreover, there are conflicts surrounding land use, especially in big cities; and in some cases, agricultural activities are undertaken in the city without the necessary landuse and building approvals. Urban green spaces are under tremendous pressure: population growth and economic developments lead to a growing need for settlement areas, particularly in conurbations.

It is recognised that collaboration and sharing can be regarded as key elements of UA. The strong role that UA may play with regard to urban networking and interaction between a wide variety of actors can primarily be explained by the special forms of organisation and marketing that are geared towards the urban setting.

In order to be able to make a real contribution to sustainable land management, it is important for UA to overcome the boundaries and obstacles relating to agricultural production in cities. This includes seeing existing competitive usages as an opportunity by further developing unused areas for multifunctional uses. For example, many unused roofs are suitable for creating rooftop gardens. Also allotments, which have come under pressure in many places, could be made available for use as green spaces by a wider public, by testing new approaches and demonstrating greater openness towards non-gardeners, ensuring their continued existence as green oases in the heart of the city.

Particularly the notion of multifunctionality, which also includes social and ecological benefits that are hard to quantify (Schulz et al. 2013), may become an important guiding principle for sustainable land management in the future, in which UA may be acknowledged as a "multifunctional service".

\section{References}

Appel, I., Grebe, C., \& Spitthöver, M. (2011). Aktuelle Garteninitiativen. Kleingärten und Gärten in deutschen Großstädten. Kassel: kassel university press.

Artmann, M., \& Sartison, K. (2018). The role of urban agriculture as a nature-based solution: A review for developing a systemic assessment framework. Sustainability, 10(6), 1937. https://doi. org/10.3390/su10061937

BBSR (Ed.). (2015). Gemeinschaftsgärten im Quartier. BBSR-Online-Publikation. No. 12/2015. Bonn. 
Berges, R., Opitz, I., Piorr, A., Krikser, T., Lange, A., Bruszewska, K., et al. (2014). Urbane Landwirtschaft. Innovationsfelder für die nachhaltige Stadt? Müncheberg: Leibniz-Zentrum für Agrarlandschaftsforschung (ZALF) e. V.

BMUB. (2015). Grün in der Stadt - Für eine lebenswerte Zukunft. Berlin: Grünbuch Stadtgrün.

Brandt, M., Gärtner, S., \& Meyer, K. (2018). Urbane Produktion, Planungsrecht und dezentrale Finanzsysteme. IAT Forschung aktuell 10/2018. Institut Arbeit und Technik (IAT). Gelsenkirchen.

Calvet-Mir, L., March, H., Nordt, H., Pourias, J., \& Čakovská, B. (2016). Motivations behind urban gardening - 'Here I feel alive'. In S. Bell, R. Fox-Kämper, N. Keshavarz, M. Benson, S. Caputo, S. Noori, \& A. Voigt (Eds.), Urban allotment gardens in Europe. New York: Earthscan from Routledge. https://doi.org/10.4324/9781315686608.

Cohen, N., \& Reynolds, K. (2014). Resource needs for a socially just and sustainable urban agriculture system: Lessons from New York City. Renewable Agriculture and Food Systems. https:// doi.org/10.1017/S1742170514000210.

Colding, J., \& Barthel, S. (2013). The potential of 'urban green commons' in the resilience building of cities. Ecological Economics, 86, 156-166. https://doi.org/10.1016/j.ecolecon.2012.10.016

Dams, C. (2012). Gärten gehören zur Stadt! Zur städtebaulichen Relevanz der urbanen Landwirtschaft. InUrban Gardening: über die Rückkehr der Gärten in die Stadt, edited by Christa Müller (5th ed., pp. 160-172). Oekom.

De Cunto, A., Tegoni, C., Sonnino, R., Michel, C., \& Lajili-djalaï, F. (2017). Food in cities: Study on innovation for a sustainable and healthy production, delivery, and consumption of food in cities. Luxembourg.

de Zeeuw, H. (2011). Cities, climate change and urban agriculture. Urban Agriculture Magazine, $25,39-42$.

Fox-Kämper, R. (2016). Concluding remarks. In S. Bell, R. Fox-Kämper, N. Keshavarz, M. Benson, S. Caputo, S. Noori, \& A. Voigt (Eds.),Urban allotment gardens in Europe. New York: Earthscan from Routledge. https://doi.org/10.4324/9781315686608.

Gahm, S. (2017). Urbane Landwirtschaft als Form der praktischen Umweltbildung für und mit sozial Benachteiligten. In Bachelorarbeit an der Fakultät Angewandte Sozialwissenschaften an der Hochschule für angewandte Wissenschaften Würzburg-Schweinfurt.

Holm, A. (2011). Das Recht auf die Stadt. Blätter für deutsche und internationale Politik, 8, 89-97.

Horst, M., McClintock, N., \& Hoey, L. (2017). The intersection of planning, urban agriculture, and food justice: A review of the literature. Journal of the American Planning Association, 83(3), 277-295. https://doi.org/10.1080/01944363.2017.1322914

Howe, U., Viljoen, A., \& Bohn, K. (2005). New cities with more life: Benefits and obstacles. In A. Viljoen, K. Bohn, \& J. Howe (Eds.), Continuous productive urban landscapes: Designing urban agriculture for sustainable cities (pp. 56-60). London: Elsiever Architectural Press.

Karge, T. (2015). Neue Urbane Landwirtschaft - Eine theoretische Verortung und Akteursanalyse der Initiative Himmelbeet im Berliner Wedding. Arbeitshefte des Instituts für Stadtund Regionalplanung der Technischen Universität Berlin, 79.

Koch, M. (2017). Möglichkeiten und Grenzen der Freiraumsicherung in urbanen Wachstumsräumen. In S. Kost \& C. Kölking (Eds.), Transitorische Stadtlandschaften: Welche Landwirtschaft braucht die Stadt? (pp. 27-40). Wiesbaden: Springer.

Lohrberg, F. (2011). Masterplan Agrikultur. Städte müssen Dialog mit Landwirten suchen. Stadt + Grün, 09, 43-48.

LWK NRW (Ed.). (2012). Landwirtschaftlicher Fachbeitrag zum Regionalplan Metropolregion Ruhr. Daten, Fakten und Entwicklungsperspektiven der Landwirtschaft im urbanen und suburbanen Raum. Unna

McClintock, C., Miewald, E., \& McCann, N. (2016). The politics of urban agriculture: Sustainability, governance, and contestation. In A. E. G. Jonas, B. Miller, K. Ward, \& D. Wilson (Eds.),The Routledge handbook on spaces of urban politics (pp. 1-15). London: Routledge.

McClintock, N., \& Simpson, M. (2017). Stacking functions: Identifying motivational frames guiding urban agriculture organizations and businesses in the United States and Canada. Agriculture and Human Values, 35(1), 19-39. https://doi.org/10.1007/s10460-017-9784-x 
McEldowney, J. (2017). Urban agriculture in Europe. Patterns, challenges and policies. European Parliamentary Research Service. https://doi.org/10.2861/790177.

Opitz, I., Berges, R., Piorr, A., \& Krikser, T. (2016). Contributing to food security in urban areas: Differences between urban agriculture and peri-urban agriculture in the Global North. Agriculture and Human Values, 33(2), 341-358. https://doi.org/10.1007/s10460-015-9610-2

Opitz, I., Zoll, F., Doernberg, A., Specht, K., Siebert, R., Piorr, A., et al. (2017). Future|FoodlCommons - Alternative food networks at the urban-rural interface. Müncheberg: Agrathaer, ZALF.

Pearson, L. J., Pearson, L., \& Pearson, C. J. (2010). Sustainable urban agriculture: Stocktake and opportunities. International Journal of Agricultural Sustainability, 8(1 \& 2), 7-19. https://doi. org/10.3763/ijas.2009.0468

Piorr, A., Zasada, I., Doernberg, A., Zoll, F., \& Ramme, W. (2018). Research for AGRI Committee - Urban and Peri-urban agriculture in the EU. Brussels: Policy Department for Structural and Cohesion Policies.

Purcell, M., \& Tyman, S. K. (2015). Cultivating food as a right to the city. Local Environment, 20(10), 1132-1147. https://doi.org/10.1080/13549839.2014.903236

Roggema, R. (Ed.). (2016). Sustainable urban agriculture and food planning. New York: Routledge.

Rosol, M. (2006). Gemeinschaftsgärten in Berlin. Eine qualitative Untersuchung zu Potenzialen und Risiken bürgerschaftlichen Engagements im Grünflächenbereich vor dem Hintergrund des Wandels von Staat und Planung. In Dissertation an der Mathematisch-Naturwissenschaftlichen Fakultät der Humboldt-Universität zu Berlin. https://doi.org/10.1109/IGARSS.2015.7326091.

RUAF Foundation (Ed.). no date. Urban agriculture: What and why?" Accessed on February 2, 2019. https://www.ruaf.org/urban-agriculture-what-and-why.

Santo, R., Palmer, A., \& Kim, B. (2016). Vacant Lots to Vibrant Plots. A review of the benefits and limitations of Urban Agriculture. Johns Hopkins Center for a Livable Future.

Sanyé-Mengual, E., Specht, K., Krikser, T., Vanni, C., Pennisi, G., Orsini, F., \& Prosdocimi Gianquinto, G. (2018). Social acceptance and perceived ecosystem services of urban agriculture in Southern Europe: The case of Bologna, Italy. PLOS ONE, 13(9), e0200993. https://doi.org/10. 1371/journal.pone.0200993.

Schmidt, D. (2016). Die Rolle der urbanen Landwirtschaft in der Stadtentwicklung: Übersicht und Umgang mit neuen Formen anhand von Fallbeispielen. In Masterarbeit an der Fakultät Umweltwissenschaften der Technischen Univesität Dresden.

Schulz, K., Weith, T., Bokelmann, W., \& Petzke, N. (2013). Urbane Landwirtschaft und "Green Production" als Teil eines nachhaltigen Landmanagements. Diskussionspapier No. 6. LeibnizZentrum für Agrarlandschaftsforschung (ZALF) e.V. Müncheberg.

Siedentop, S. (2010). INNENENTWICKLUNG/AUSSENENTWICKLUNG". In D. Henckel, von Kuczkowski, K., Lau, P., Pahl-Weber, E., \& Stellmacher, F. (Eds.), Planen - Bauen - Umwelt (pp. 235-240). Wiesbaden: VS Verlag für Sozialwissenschaften. https://doi.org/10.1007/978-3531-92288-1_1.

Simons, H., \& Weiden, L. (2016). Schwarmverhalten, Reurbanisierung und Suburbanisierung. Informationen zur Raumentwicklung, 3, 263-273.

Smit, J., Nasr, J., \& Ratta, A. (2001). Urban agriculture: Food, jobs and sustainable cities. UNDP. New York: The Urban Agriculture Network, Inc.

Sondermann, M. (2014). Local cultures of urban gardening and planning in Germany. In Riga event report: Urban allotment gardens in European cities - Future, challenges and lessons learned (COST Action TU1201). Accessed on June 20, 2020. https://www.urbanallotments.eu/fileadmin/ uag/media/D_Meetngs/Riga/Riga_Report_Final_NK.pdf

Specht, K., Reynolds, K., \& Sanyé-Mengual, E. (2017). Community and social justice aspects of rooftop agriculture. In F. Orsini, M. Dubbeling, H. de Zeeuw, \& G. Gianquinto (Eds.), Rooftop urban agriculture (pp. 277-290). Cham: Springer International Publishing. https://doi.org/10. 1007/978-3-319-57720-3_17. 
Specht, K., \& Siebert, R. (2017). Städtische Landwirtschaft in, an und auf Gebäuden: Möglichkeiten für die Stadtentwicklung, Handlungsfelder und Akteure. In S. Kost \& C. Kölking (Eds.), Transitorische Stadtlandschaften: welche Landwirtschaft braucht die Stadt? (pp. 95-114). Wiesbaden: Springer.

Stierand, P. (2012). Stadtentwicklung mit dem Gartenspaten. Umrisse einer Stadternährungsplanung. Dortmund. https://speiseraeume.de/downloads/SPR-Stadternaehrungsplanung-Stierand. pdf.

Thibert, J. (2012). Making local planning work for urban agriculture in the North American context. Journal of Planning Education and Research, 32(3), 349-357. https://doi.org/10.1177/073945 6X11431692

UNDP (Ed.). (1996). Urban Agriculture. Food, jobs and sustainable cities. New York.

van der Jagt, A. P. N., Szaraz, L. R., Delshammar, T., Cvejić, R., Santos, A., Goodness, J., \& Buijs, A. (2017). Cultivating nature-based solutions: The governance of communal urban gardens in the European Union. Environmental Research, 159, 264-275. https://doi.org/10.1016/j.envres.2017. 08.013

van der Schans, J., Willem, W. L., Alfranca, Ó, Alves, E., Andersson, G., Branduini, P., et al. (2016). It is a business! Business models in urban agriculture. In F. Lohrberg, L. Lička, L. Scazzosi, \& A. Timpe (Eds.), Urban agriculture Europe (pp. 82-91). Berlin: Jovis.

Vejre, H., Eiter, S., Hernández-Jiménez, V., Lohrberg, F., Loupa-Ramos, I., Recasens, X., et al. (2016). Can agriculture be urban? In F. Lohrberg, L. Lička, L. Scazzosi, \& A. Timpe (Eds.), Urban agriculture Europe (pp. 18-21). Berlin: Jovis.

Viljoen, A., Bohn, K., \& Howe, U. (Eds.). (2005). Continuous productive urban landscapes: Designing urban agriculture for sustainable cities. London: Elsiever Architectural Press.

Voicu, I., \& Been, V. (2008). The effect of community gardens on neighboring property values. Real Estate Economics, 36(2), 241-283.

Zoll, F., Specht, K., Opitz, I., Siebert, R., Piorr, A., \& Zasada, I. (2018). Individual choice or collective action? Exploring consumer motives for participating in alternative food networks. International Journal of Consumer Studies, 101-110. https://doi.org/10.1111/ijcs.12405.

Open Access This chapter is licensed under the terms of the Creative Commons Attribution 4.0 International License (http://creativecommons.org/licenses/by/4.0/), which permits use, sharing, adaptation, distribution and reproduction in any medium or format, as long as you give appropriate credit to the original author(s) and the source, provide a link to the Creative Commons license and indicate if changes were made.

The images or other third party material in this chapter are included in the chapter's Creative Commons license, unless indicated otherwise in a credit line to the material. If material is not included in the chapter's Creative Commons license and your intended use is not permitted by statutory regulation or exceeds the permitted use, you will need to obtain permission directly from the copyright holder.

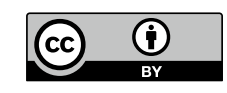

